\title{
A Buddhist monastery revealed by UAV survey and ground-penetrating radar in eastern Mongolia
}

\author{
Erdene Myagmar ${ }^{1}$, Henry Webber ${ }^{2}$, Geoffrey Parkes ${ }^{3}$, Vito Pecchia ${ }^{4}$ \\ $\&$ Mark Horton ${ }^{2, *}$
}

The site of the Dzuun Khuree monastery in the Upper Kherlen Valley of eastern Mongolia was recently investigated by UAV and ground-penetrating radar. The monastery's highly unusual circular form and layout suggest a foundation earlier than previously suspected.

In 2012, satellite images appeared online that revealed the remains of a circular and wellplanned archaeological site (Figure 1) on the west bank of the Kherlen River, $25 \mathrm{~km}$ south of Mongonmorit soum, Mongolia (48 0.806N/108 29.833E). Since 2008, a joint University of Bristol/National University of Mongolia expedition has been studying the archaeology of the Upper Kherlen Valley, and this feature was of immediate interest (Horton et al. 2012). Radiating buildings from a number of central structures were visible in the light snow cover in this image. Following a GPS and magnetometer survey in 2014 (Horton et al. 2015), we realised that the site was ideal for testing ground-penetrating radar (GPR) in the Mongolian grasslands. In 2016, we used UAV survey to capture a detailed map of the site, and then employed GPR to investigate specific features.

The site is known locally as Dzuun Khuree, Kherlen golyn zuun khuree, Khoegshin Khuree and Uvgun khuree (Maidar 1972: 100; Rinchen \& Maidar 1979: 56). The features captured in the UAV imagery are undoubtedly the remains of a former monastery. This was mapped by Klyagina-Kondratiyeva (2013: 182) in 1929, and recently included in the 'Documentation of Mongolian Monasteries' project. The monastery belonged to the 'yellow robe' (Gelugpa) sect of Buddhism and was located below the sacred Togos Kharkhan mountain. It had around 1200 monks and was one of the largest religious and trade centres in central Mongolia, the monastic city of the second Bodg Jebtsundamba, Luvsandambiydonmi (1724-1757) and renowned as one of the five cherished places of Undur Gegeen Zanabazar (1635-1723) (Tsedendamba 2009). Traditions place its foundation in either 1691 (DOMM Study 2004) or 1701, while Pozdneev (1971: 303), citing the Erdeni-yin Erike chronicle, claimed that it was founded in year 50 of EnkhAmgalan Khan (1711). There are, however, reasons to believe that the monastery may be

\footnotetext{
Department of Archaeology and Anthropology, National University of Mongolia, Ulaanbaatur 14200, Mongolia Department of Anthropology and Archaeology, University of Bristol, 43 Woodland Road, Bristol BS8 $1 U U, U K$ Western Region, Royal Geographical Society, clo 1 Kensington Gore, London SW7 2AR, UK

VPP Architects, 104 Northend, Batheaston, Bath BA1 7HA, UK

Author for correspondence (Email: clmch@bristol.ac.uk)
} 


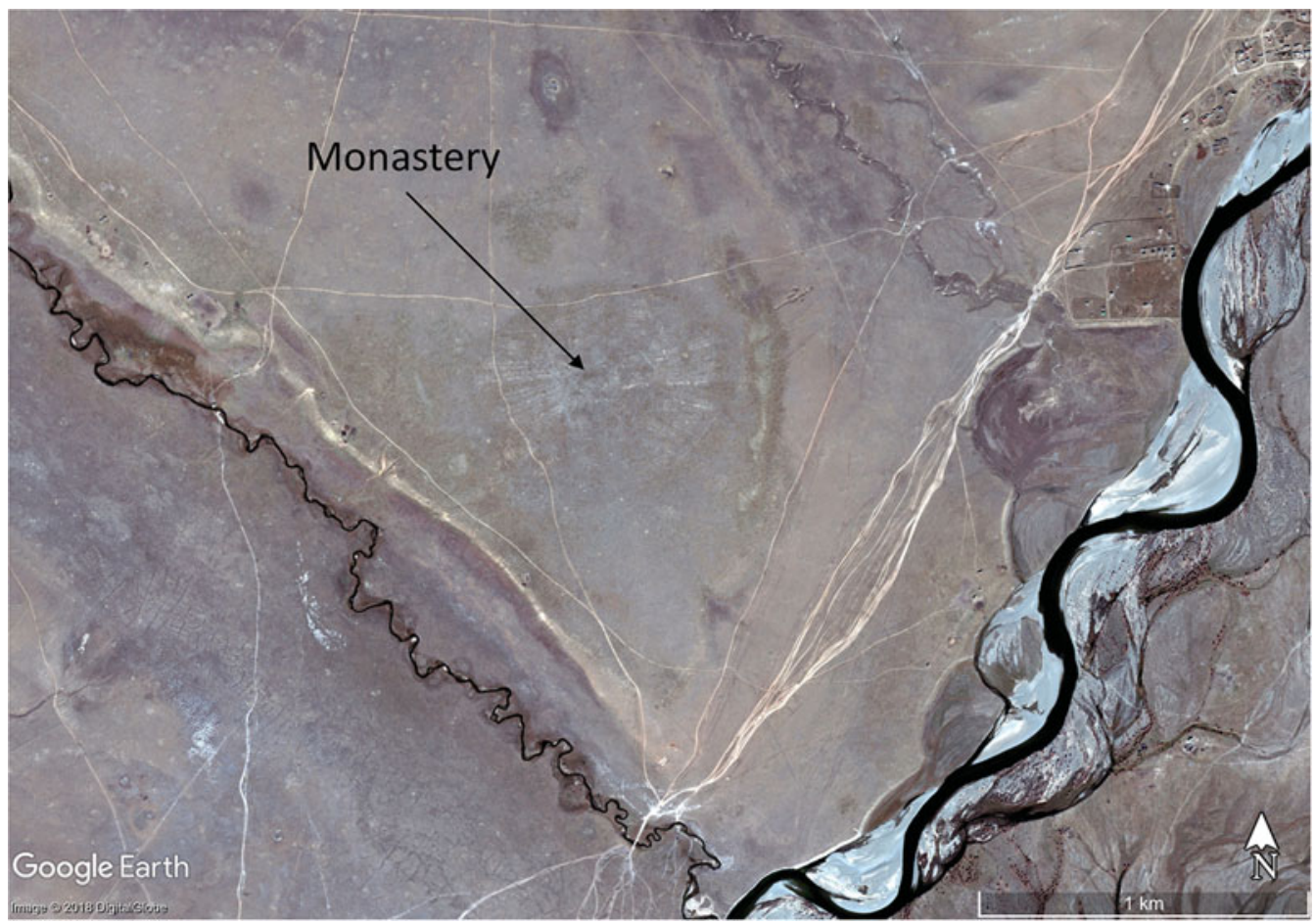

Figure 1. Google Earth/DigitalGlobe image showing the Dzuun Khuree monastery on the west bank of the Kherlen River, taken 10 October 2012.

older than these conflicting records suggest - a view also shared by Pozdneev, who visited the working monastery in 1896 . The monastery was suppressed in 1937, the buildings destroyed and the monks dispersed.

\section{Description of the site}

The site is located on a flat alluvial terrace between the Kherlen River and two smaller streams. On the surface there is very little to see, beyond discoloured grass, and low mounds marking the position of 28 stupas surrounding the site. The UAV survey was conducted with a DJI Phantom 3 Professional, and the orthomosaic (Figure 2a) processed using the drone deploy platform (http://dronedeploy.com). Elevation and hillshade imagery from the digital elevation model (Figure $2 \mathrm{~b}$ ) were also generated from high-resolution images (2ins/pixel). From this data and the ground surveys, a detailed and accurate plan was compiled (Figure 3). The monastery covers an oval area of $750 \times 600 \mathrm{~m}$. In the centre, there are 17 temples or religious colleges, while to the east and west are 24 radiating aimags (monastic dormitories), each sub-divided into individual cells that housed traditional ghers (circular tents).

Between the temples and the aimags is a path that may represent a processional route around the central precinct. There is a central axis through the site that runs east to west, along with north and south entrances. The temples have traces of internal structures laid (C) Antiquity Publications Ltd, 2018 

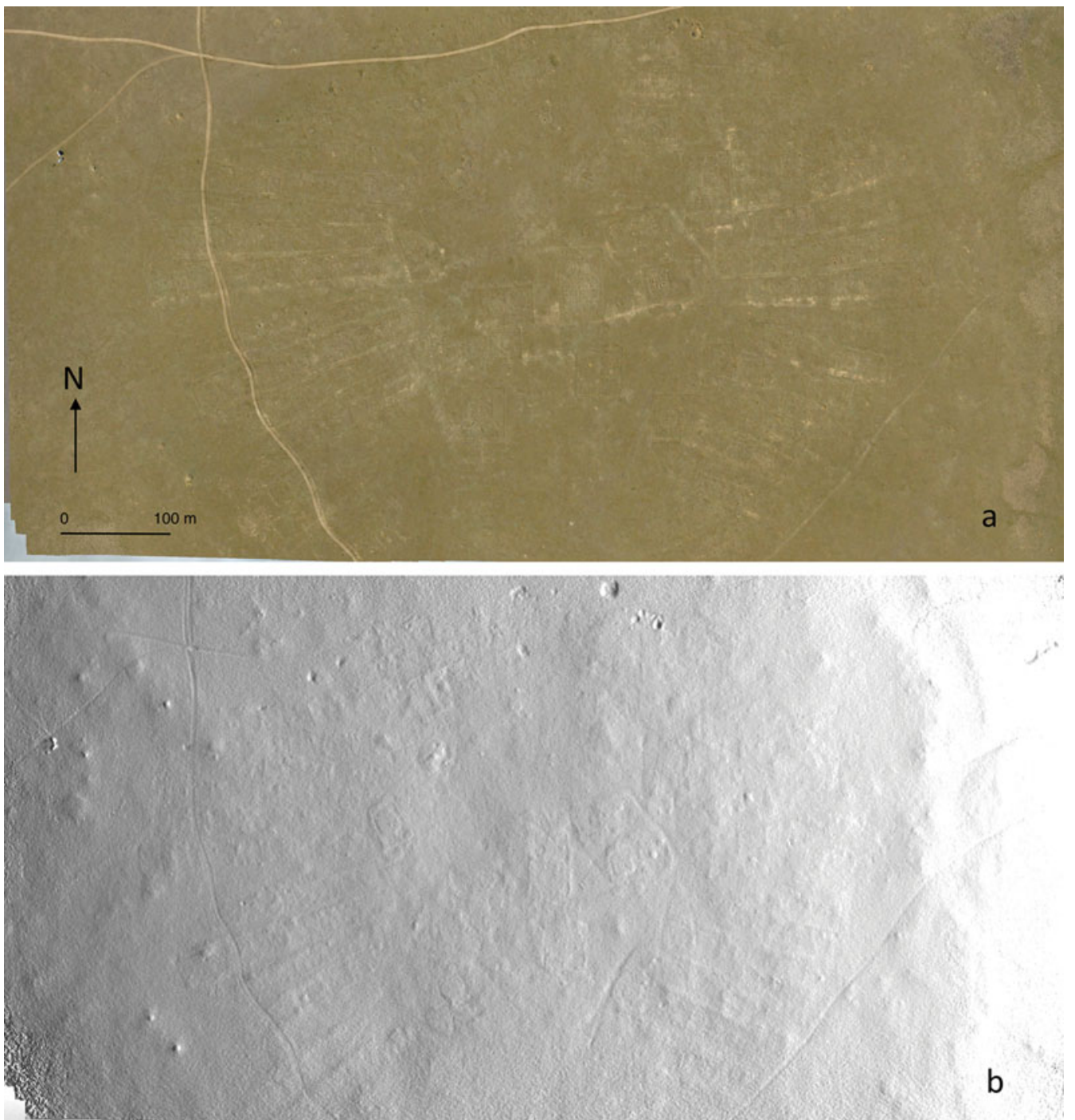

Figure 2. A) Dzuun Khuree UAV orthomosaic photograph; B) hillshade model of monastic site. Survey performed in 2016 (credit: authors).

out with small stones, including circles and squares. These could have been to demarcate gher temples. At least three temples also contained a grid of timber posts that supported a floor and a timber superstructure. The most impressive, temple five, has a grid of $9 \times 9$ posts, with three circles marked out to the north, representing small ghers within the temple enclosure. The walls of each temple were probably of timber construction, built on slightly raised banks that might have formed the base of earlier mud-brick walls. We conducted GPR surveys over several of the temples. Temple five was the most informative (Figure 4), with data enabling an estimate for posthole depth of around $0.8 \mathrm{~m}$, the location of additional

(C) Antiquity Publications Ltd, 2018 


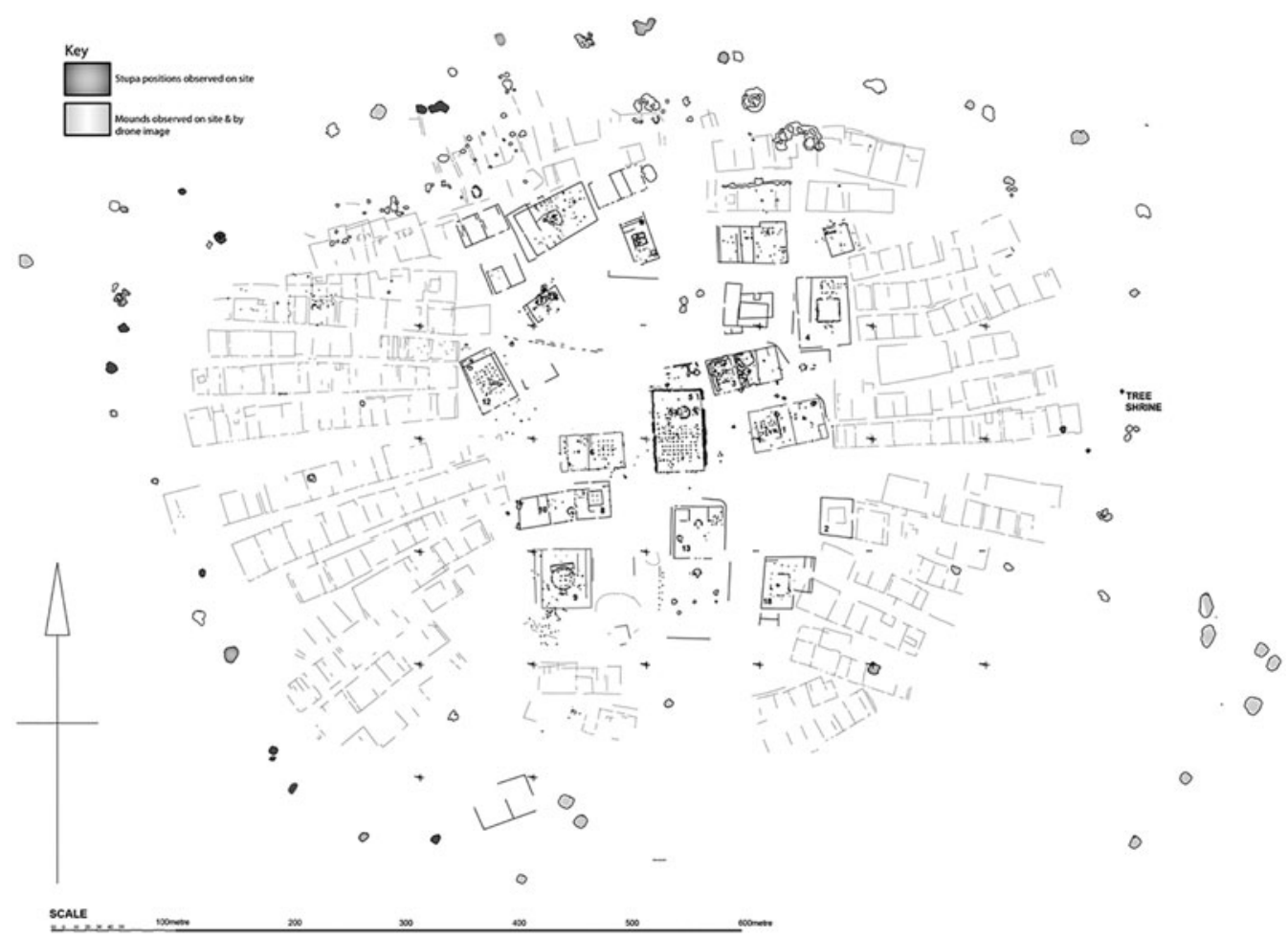

$\circ 0$

Figure 3. Plan of the Dzunn Khuree monastic site, compiled from UAV imagery and on-site survey, 2014-2016 (drawn by Vito Pecchia).

gher structures and the suggestion of sub-features below two of the gher enclosures. Similar anomalies were also found below other gher temples.

A number of gravel mounds surrounded the site-mostly along the north and west sides-measuring approximately $8 \mathrm{~m}$ in diameter and up to $1.5 \mathrm{~m}$ high. Some contained both fired red and grey mud-bricks, and stone slabs. Although most were heavily robbed, 28 could be recognised as stupa bases. Several also contained broken terracotta plaques (Figure 5) of a particular quality and form associated with the Zanabazar revival of the seventeenth to nineteenth centuries (Berger \& Bartholomew 1995: 304). On the eastern side of the site was a tree shrine (Figure 6) with a ring of stones and a single step. While the veneration of trees is common in Buddhism, it is unusual in the treeless Mongolian landscape.

\section{Discussion}

The Dzuun Khuree monastery is also unusual in its circular form, with its large number of central temples and radiating aimags, and may reflect the plan of secular camps (or orda). Most Mongolian monasteries have a rectilinear plan, the only other known circular (C) Antiquity Publications Ltd, 2018 

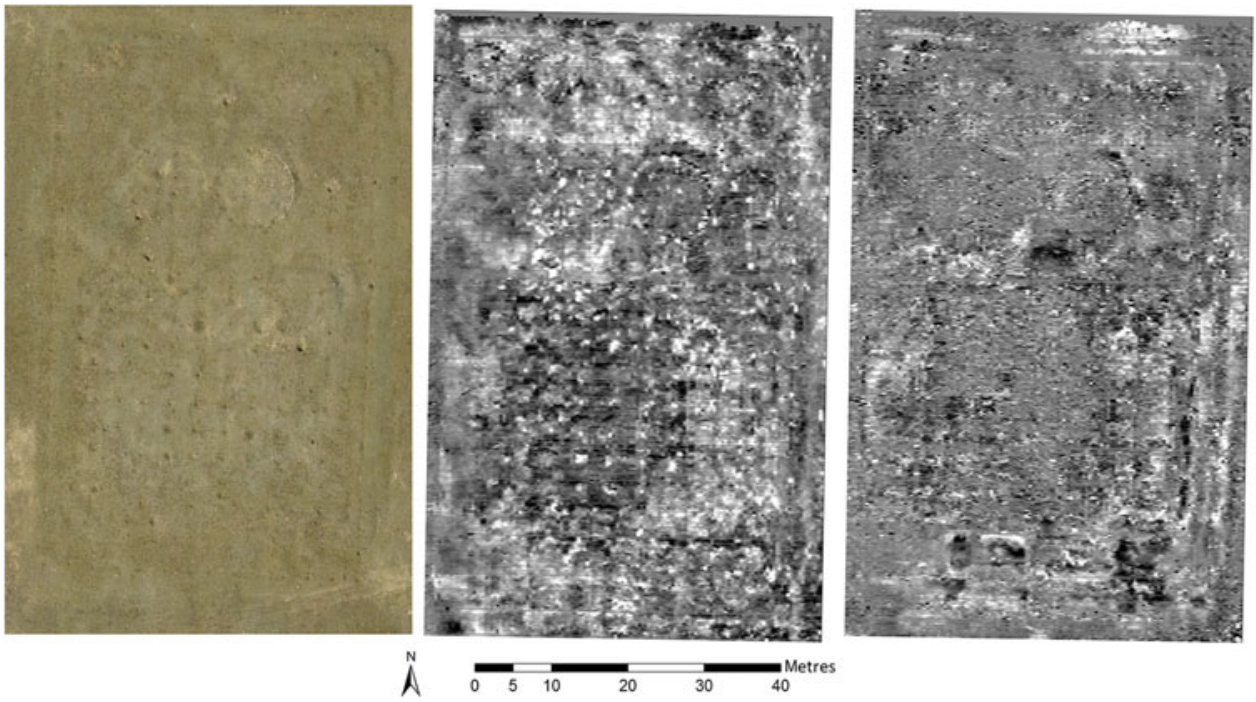

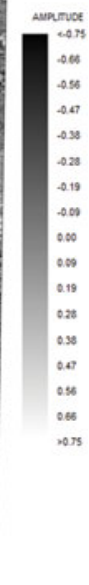

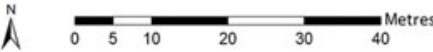

Figure 4. Temple five, UAV image and ground-penetrating radar time-slice image at 1 ns and $4 n s$ (approximately $0.2 \mathrm{~m}$ and $0.8 \mathrm{~m}$ depth at a velocity of $1.5 \mathrm{~m} / \mathrm{ns}$ ) (credit: authors).



Figure 5. Terracotta plaques from disturbed context of stupa two, probably seventeenth century (Zanabazar period); Buddha in meditation, in Single Lotus pose (photograph by Mark Horton). 


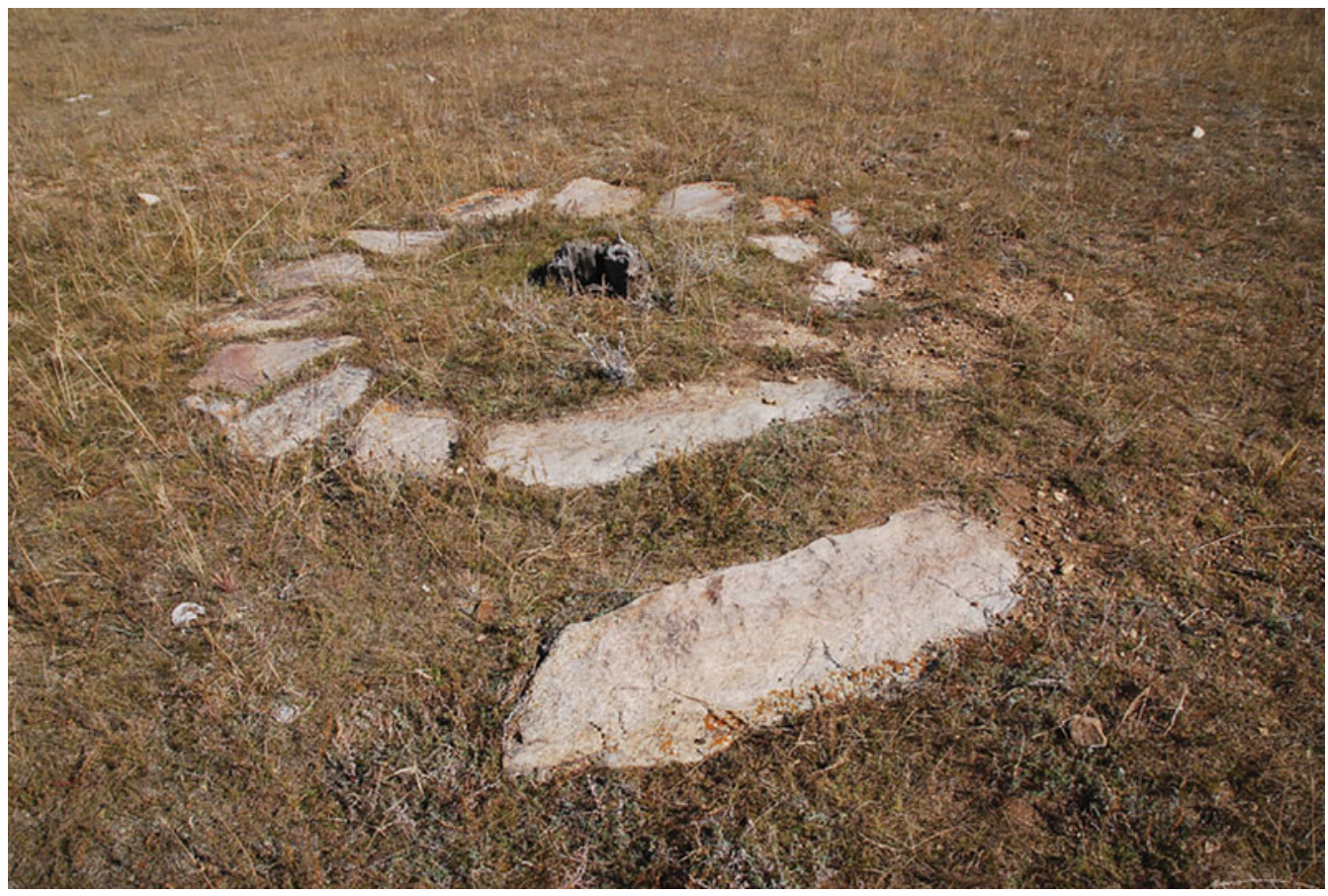

Figure 6. Remains of a tree shrine, with remaining stump and stones used to mark the site, facing north-east (photograph by Mark Horton).

examples being Ikh Khuree and the adjacent_and still surviving_Gandan monastery in Ulaanbaatar. Both are recorded on a 1913-1915 plan, now in the Zanabazar Museum. Ikh Khuree, known then as Urgu, was founded in $c$. 1639, and moved on multiple occasions before settling at Ulaanbaatar in 1778 (Berger 1995: 66). Gandan was founded in 1809. Dzuun Khuree may pre-date both these. Another clue that it may be earlier is the grid of posts, found in at least three of the temples that supported the floor and superstructure. This arrangement is recorded, for example, in the thirteenth-century 'Great Hall' temple at Karakorum (Franken 2015) and in wider Buddhist architecture in Japan and China. The possibility that the monastery might belong to the Mongol period, therefore, should not be wholly discounted.

\section{References}

Berger, P. 1995. After Zanadu. The Mongol renaissance of the sixteenth to eighteenth centuries, in P. Berger \& T.T. Bartholomew, Mongolia: the legacy of Chinggis Khan: 50-75. New York: Thomas $\&$ Hudson.

Berger, P. \& T.T. Bartholomew. 1995. Mongolia: the legacy of Chinggis Khan. New York: Thomas \& Hudson.

(C) Antiquity Publications Ltd, 2018
Documentation of Mongolian Monasteries. n.d. Available at: http://mongoliantemples.org/index. $\mathrm{php} / \mathrm{en} / \mathrm{component} / \mathrm{domm} / 1710$ ?view= oldtempleen (accessed 29 May 2018).

DOMM Study. 2004. Information collected by surveyors in the DOMM pilot study in 2004 in Tov Aimag. Ulaanbaatur: Cultural Heritage Program of the Mongolian Council. Available at: http://mongoliantemples.org/ampdfs/TOMM_ 051_AM.pdf (accessed 29 May 2018). 


\section{A Buddhist monastery revealed by UAV survey and ground-penetrating radar in eastern Mongolia}

Franken, C. 2015. Die 'grosse Halle' von Karakorum: zur archäologischen Untersuchung des ersten buddhistischen Tempels der alten mongolischen Haupstadt (Forschungen Zur Archaologie Aussereuropaischer Kulturen 12). Wiesbaden: Reichert (in German).

Horton, M., T. Dashtseveg \& E. Myagmar. 2012. Kherlen Valley survey, eastern Mongolia (2009-2011). Ancient cultures of Mongolia and the Baikalian Siberia: $3^{\text {rd }}$ International Scientific Conference (Ulaanbaatur, September $5^{\text {th }}-9^{\text {th }}$ 2012) (Volume 2). Ulaanbatuur: School of Social Sciences, National University of Mongolia.

Horton, M., M. Erdene, V. Pecchia \& G. Parkes. 2015. Survey results at Dzuun Khuree monastic site, eastern Mongolia. Proceedings of VI International Academic Conference: ancient cultures of Mongolia, Baikalian of Siberia and the northern area of China: (Huhbot Inner Mongolia, People's Republic of China) $12^{\text {th }}-16^{\text {th }}$ October, 2015.
Klyagina-Kondratiyeva, M.I. 2013. Mongolian Buddhist culture: a study of monasteries and temples in Khentii and Khangal, in S. Chuluun \& T.I. Yusupova (ed.) Senri ethnological reports 113. Osaka: National Museum of Ethnology.

MAIDAR, D. 1972. Architecture and city construction of Mongolia (Монголын архитектур ва хот байгуулалт). Ulaanbaatar: State Printing House (in Mongolian).

Pozdneev, A.M. 1971. Mongolia and the Mongols. Edited by J.R. Krueger and translated by J.R. Shaw \& D. Plank. Bloomington: Indiana University Press.

Rinchen, B. \& D. Maidar. 1979. Atlas of ethnography and linguistics of People's Republic of Mongolia (Бүгд Найрамдах Монгол Ард Улсын угсаатны зүй, хэл шинжлэлийн атлас). Ulaanbaatar: Academy of Science of the People's Republic of Mongolia (in Mongolian).

Tsedendamba, S. 2009. History of monasteries and temples of Mongolia (Монгольнн сүм хийдийн $m_{Y Y}$, сүм хийдийн түY). Ulaanbaatar: Admon (in Mongolian). 